\title{
MELODIA RÓŻNIE NAKRĘCONA
}

Hokeiści Węgier, którzy w 2016 roku, w Moskwie, toczyli boje w najwyższej, nazywanej elitą, grupie rozgrywek o mistrzostwo globu, kultywowali po zakończeniu meczów zwyczaj (a może manierę) śpiewania a cappela hymnu państwowego. Czynili to razem ze swymi kibicami. Dla kilku graczy o rodowodzie rumuńskim i duetu zawodowców importowanych z Kanady była to niewątpliwie trudna próba dostrojenia się do chóru i potwierdzenia nie tylko sportowej tożsamości.

Wprowadzenie jako dodatkowej konkurencji sportowej zespołowego wykonywania najważniejszej pieśni państwowej znacznie osłabiłoby potencjał reprezentacji piłkarzy ręcznych Kataru, wywodzących się z Kuby, Hiszpanii, Słowenii lub Francji. Wiadomo również, że problemy z mruczeniem pod nosem melodii państwa docelowego mieliby liczni Brazylijczycy dopraszani do europejskich drużyn reprezentacyjnych w futbolu oraz wielu Etiopczyków biegających na stadionach ku chwale Azerbejdżanu, Holandii i Szwecji.

Równość szans to jeden z najczęściej przywoływanych banałów rywalizacji sportowej. W defiladach otwierających igrzyska olimpijskie maszerują grupami ludzie oddzieleni od innych ludzi jedynie sztandarami i tablicami z nazwami państw. Ale już za chwilę pojedynki na tej samej dla wszystkich murawie, identycznej planszy, przeznaczonej wszystkim macie lub w niezmiennej dla każdego wodzie basenu, muszą wyłonić lepszych od innych, a zatem również godziwiej od konkurentów opłacanych. Kapitały sportowe poszczególnych państw niewiele zatem różnią się od tych, które dają przewagę w bojach o banany lub ropę naftową, a bieżnia jest tylko na tyle płaska, na ile planeta bywa dla każdego okrągła, pozwalając dotrzeć ludziom białym, czarnym i żółtym w to samo miejsce.

Być może bliski jest moment, gdy na olimpiadach rywalizować będą nie państwa, lecz globalne koncerny i korporacje, a zwycięzcom wciągną na maszt logo firmowe lub reklamowy slogan. W takiej lidze dla siłaczy, mistrzów refleksu i szybkobiegaczy, o przynależności do konkretnej drużyny nie zadecydują dane osobowe w paszporcie, ale precyzyjnie spisany kontrakt.

\footnotetext{
* MGR PIOTR ZACZKowski - Uniwersytet Śląski w Katowicach, e-mail: piotr.zaczkowski@miasto-ogrodow.eu
} 
Póki co jednak trwa ważne - i nie pozbawione piękna - złudzenie. Wypada zgodzić się z Józefem Lipcem, że w rywalizacji na igrzyskach olimpijskich -,,państwo akceptowane, cenione, kochane przez sportowca staje się naturalnym składnikiem występu sportowca lub drużyny". Dodajmy - występu, który dzieje się nie tylko przed publicznością obecną $\mathrm{w}$ określonym tu i teraz na stadionie, ale zwielokrotnioną w odbiorze medialnym. Po zwycięskim finale na igrzyskach w Monachium piłkarze „stoją stłoczeni obejmując się ramionami. Stuchaja hymnu wraz z nami" ${ }^{2}$. W jakimś możliwie powszechnym czasie teraźniejszym wypełnia się czas nadzwyczajnego święta zbiorowego i gromadnego oraz państwowego, gdyż igrzyska olimpijskie są konfrontacją zawodników, którzy muszą mieć państwową, a niekoniecznie narodową, akredytację.

Od wątku państwowego bardzo blisko do nuty propagandowej. Niekiedy brzmiącej mocno fałszywie. Zbigniew Kaczmarek podniósł złoto igrzysk w dwuboju wagi lekkiej 21 lipca 1976 roku. Mazurek Dąbrowskiego, zagrany sztangiście na igrzyskach w Montrealu, uznano za upominek godny Polski Ludowej, w przeddzień jej święta, obchodzonego w rocznicę ogłoszenia manifestu Polskiego Komitetu Wyzwolenia Narodowego. Złoto po kilku miesiącach odwołano, gdyż okazało się, że Kaczmarka wspomagały sterydy anaboliczne. $Z$ jednej strony prawdziwa bywa więc formuła Ervinga Goffmana, że „świat jest $w$ istocie uroczystościa, w której wszyscy bierzemy udzial" ${ }^{3}$. Z drugiej strony, zawody ciężarowców - zresztą nie tylko w dobie propagandy sukcesu i nie jedynie za przyczyną zawodniczych przygód Zbigniewa Kaczmarka - są niekiedy olimpijskim oszustwem, w którym mimowolnie wszyscy bierzemy udział.

Więcej pożytku propaganda miała z zimowych igrzysk w Sapporo w 1972 roku. Była to pierwsza tak znacząca impreza sportowa, która odbywała się po wymianie ekipy zarządzającej krajem. Jak skrzętnie obliczono (nie pomijając laurów w konkursach sztuki), wcześniejsze polskie zdobycze olimpijskie liczyły 99 medali. Do Japonii wyprawiono sportowców po setny medal, którego jubileuszowy walor miał potwierdzać sportową wielkość Polski pod dowództwem Edwarda Gierka. Zaskakująca wygrana na igrzyskach skoczka Wojciecha Fortuny była więc tyle sportowa, ile polityczna. Formą przedłużenia złotego rytuału stało się uhonorowanie dziewiętnastolatka z Zakopanego Złotym Odznaczeniem im. Janka Krasickiego (mimo że sportowiec nigdy nie był członkiem Związku Młodzieży Socjalistycznej) i Złotym Krzyżem Zasługi (mimo że zasłużył się jednym wyłącznie skokiem).

Ważnym składnikiem wyraźnie zwizualizowanej narracji o zgoła innej politycznej wymowie był pamiętny gest autorstwa Władysława Kozakiewicza, pokazany szowinistycznej publiczności na stadionie olimpijskim w Moskwie. Kulminacją

1 J. Lipiec, Sympozjon olimpijski, Kraków: Wydawnictwo Fall 2014, s. 53.

2 B. Tomaszewski, Listy oldboya czyli olimpijskie Samosierry, Warszawa: Wydawnictwo „Sport i Turystyka" 1974, s. 97.

${ }^{3}$ E. Goffman, Czlowiek w teatrze życia codziennego, Warszawa: Wydawnictwo KR 2000, s. 65. 
mistrzowskiego skakania i efektownego zginania łokcia było odegranie Mazurka Dąbrowskiego. W tym konkretnym olimpijskim momencie hymn państwowy stał się - jak twierdzi Kozakiewicz - „największym watem dla publiczności”" Zdecydowanie bardziej neutralne są refleksje Tomasza Majewskiego, dwukrotnego mistrza olimpijskiego czasów późniejszych - „(...) na podium tylko słucham. Bo to taki koncert dla mnie"s. Inny złoty medalista, Michał Jeliński, zwycięzca wioślarskiego wyścigu czwórek na igrzyskach w Pekinie zasłynął z widowiskowego szlochania - ,(...) emocje się skumulowaty $i$ eksplodowaty, kiedy trybuny ucichty $i$ ustyszatem hymn. Nie wstydze się tych tez. Teraz kibice pytaja, który z nas tak tadnie szlochat"'.

Hymn to dla sportowca melodia wzruszająco nakręcona. Niekiedy, mimo że grana sportowcowi wielokrotnie podczas zawodów niższej rangi, na igrzyskach niedostępna. Oszczepnik Janusz Sidło osiągnął w swej konkurencji wyżyny, a jednak „brakowato (...) tylko samego uroczystego aktu koronacji na najwyższym stopniu olimpijskiego podium, przy dźwiękach Mazurka Dąbrowskiego..." . Więcej szczęścia miała Elżbieta Duńska-Krzesińska. Jej zwycięstwo na igrzyskach w Melbourne miało ponadto szczególny wymiar w konfrontacji znaków. Zawodniczka wspominała: „,...) gdy zabrzmiały dźwięki Mazurka Dąbrowskiego i zobaczyłam polska flage wciagana na najwyższy maszt przykre refleksje odptynęty. Pozostała radość, że ja, dziewczyna z Polski, zniszczonego w czasie wojny kraju, stoję na najwyższym podium, a obok radziecka zawodniczka Dwaliszwili i Amerykanka White. Bytam dumna, że wygrałam $w$ szlachetnej sportowej rywalizacji z przedstawicielkami dwóch najpotężniejszych krajów".

Z potężnymi krajami może ułożyć się sportowo lepiej lub gorzej, zawsze jednak niespecjalnie układa się, kiedy państwowe emblematy mają życzeniową naturę. $\mathrm{Na}$ igrzyskach w Meksyku wygrywa szablista Jerzy Pawłowski. W reportażu Włodzimierza Strzyżewskiego „rozbrzmiewa hymn Polskiej Rzeczypospolitej Ludowej, na maszty wplywaja flagi Polski, Zwiąku Radzieckiego i Węgier-jak symbol braterstwa naszych krajów"9. Pawłowskiemu, który na długo przed meksykańską olimpiadą począł świadczyć usługi dla Centralnej Agencji Wywiadowczej, na pewno nie było nawet odrobinę bratersko ze Związkiem Radzieckim i jego satelitami.

$\mathrm{Na}$ tych samych igrzyskach w Meksyku, podczas których ozłocono szablę Pawłowskiego, Tom Smith, zwycięstwa biegu na 200 metrów, i trzeci na mecie John Carlos, podczas ceremonii dekoracji, unieśli zaciśnięte dłonie w czarnych rękawiczkach. Smith oświadczył na konferencji prasowej: „,pochyliliśmy głowy

${ }^{4}$ W. Kozakiewicz, M. Pol, Nie mówcie mi jak mam żyć, Warszawa: Agora SA 2013, s. 226.

5 W. Staszewski, Śpiewać hymn nie każdy może, „Gazeta Wyborcza” („Duży Format”) 14.11. 2010.

6 Tamże.

7 Sportowcy trzydziestolecia, Warszawa: Wydawnictwo „Sport i Turystyka” 1974, s. 103.

8 Tamże, s. 261.

9 W. Strzyżewski, Zlota szabla [w:] Opowiadania sportowe, Warszawa: Wydawnictwo „Sport i Turystyka" 1971, s. 148. 
w czasie grania hymnu, aby uczcić pamięć zamordowanych - Martina Luthera Kinga, Malcolma X oraz wielu innych. Uczyniliśmy to, aby caty świat wiedziat o solidarności wszystkich czarnych $w$ walce o równouprawnienie"10. W cztery lata później, w trakcie igrzysk w Monachium - przeciwko własnemu państwu zademonstrowali zwycięzca 400 metrów Vincent Matthews i srebrny medalista Wayne Collett. Zagrano hymn, według Daniela Passenta Amerykanie ,stali z założonymi rękoma, kręcili się, rozmawiali na oczach całego stadionu i telewidzów. Po uroczystości widownia wygwizdała zwycięzców" ${ }^{\prime 11}$. Na trzecim stopniu podium stał wówczas Kenijczyk Julius Sang, także ciemnoskóry sportowiec. Starał się nie dostrzegać błaznujących Amerykanów, wyprężony, poważny, z kamienną twarzą wysłuchał hymnu amerykańskiego. Za późnego wnuka czterystumetrowców z USA mógłby uchodzić triumfator ostatnich igrzysk w Rio, niemiecki dyskobol Christoph Harting, który wykonywał na podium ruchy taneczne czy ściślej dyskotekowe, pogwizdując niekoniecznie w zgodzie z odgrywanym patosem państwowego hymnu. „Lubię rytmiczna muzykę - tłumaczył dziennikarzom sportowiec - ale do naszego hymnu narodowego ciężko się tańczy"

Tak odegrane komedie, niezależnie od motywów, nie tylko burzą poczucie ładu, ale szydzą ze sportowych dramatów. Zmagania na stadionie, pływalni lub w hali są być może konfliktem zastępczym, ale najbardziej widowiskowym i paradoksalnie w największym stopniu intymnym, gdyż pozwalają rozpoznać to, co osobiście waleczne i po swojemu tchórzliwe. Wielkie i piękne kłamstwo zawodów, w których rywalizują państwowe drużyny, polega na tym, że widzowie konsumują radości i smutki jako przedstawiciele nie gatunku, ale plemienia, którego najlepsi przedstawiciele biegają jeden za drugim, skaczą do piasku albo do wody, wsiadają na rowery i dosiadają rączych rumaków.

Na igrzyskach w Meksyku Felipe Muñoz zapowiedział, że zwycięży albo umrze. Dopłynął pierwszy, co oszczędziło komentatorom spekulacji o wpływie etykiety samurajów na zachowania Meksykanów specjalizujących się w pływaniu stylem klasycznym. Dopłynąwszy, Muñoz ochłonął i poprowadzono go na podium. Zagrano mu hymn meksykański, któremu wtórowało kilka tysięcy rodaków oglądających na żywo zawody. Zwycięzca, mimo że pojedynczy był zwycięzcą zbiorowym i nie prywatnym, a znacjonalizowanym. W publikowanych po fakcie medalowych tabelach dopisano jeden złoty, ale kronikarzom wydawało się, że dopisują chwałę i akapity godności szybszej od innej godności, lepszej o kilka drobin zmierzonego u kresu walki czasu. Wiele lat później cień Muñoza zabłądził do tekstu dziennikarza, który skomentował genezę wiktorii Justyny Kowalczyk w Soczi: „Justyna wczoraj powiedziała sama sobie: Biegnę na catość, mam wszystko w nosie. Albo wygram,

${ }_{10}$ T. Olszański, Osobista historia olimpiad, Warszawa: Wydawnictwo Studio EMKA 2004, s. 51.

${ }^{11}$ D. Passent, Biada, wołajcie, lecz niech zwycięża radość [w:] Sport niejedno ma imię, Warszawa: Wydawnictwo „Sport i Turystyka” 1976, s. 49.

12 http://eurosport.onet.pl/rio-2016/lekkoatletyka/niemcy-wsciekli-na-zachowanie-christophahartinga/43vmwr 
albo zdechnę! I Meksykanin i Kowalczyk dokonali wielkiej rzeczy. To właśnie sa prawdziwi mistrzowie. Do takich ludzi należy świat!'”3. Wiele jednak wskazuje, że (nie tylko przy okazji igrzysk olimpijskich) należy obawiać się świata, który miałby należeć wyłącznie do zwycięzców lub jedynie do samobójców.

Tak naprawdę w zdobywaniu olimpijskich laurów niewiele eschatologii, a znacznie więcej stereotypu i banału. Uczestnik każdej gry społecznej, jak zauważył Erving Goffman - „ma niewiele ról i niewiele twarzy do wyboru” ${ }^{14}$. Tak więc w Soczi Kowalczyk ,stała na najwyższym stopniu podium, widziała przed soba olimpijski znicz i wznosząca się na maszcie polska flagę. Co chwile uśmiechata się, żeby zaraz próbować być poważniejsza" ${ }^{\prime 1}$. Kamil Stoch uwieńczony na tych samych igrzyskach ,(...) byt cały czas na pograniczu płaczu ze wzruszenia i śmiechu z radości. Te dwie emocje walczyly ze soba w naszym podwójnym mistrzu olimpijskim, czego efektem byt szeroki uśmiech $i$ wilgotne oczy" ${ }^{\prime 16}$. Zbigniew Bródka, trzeci Polak uhonorowany w Soczi złotem ,....) wpatrywat się w jakiś punkt w przestrzeni $i$ wyglądat na czlowieka, do którego jeszcze nie dotarto, czego dokonat"17. To, co się w tych przypadkach zwizualizowało, zaprezentowało, uzewnętrzniło, było nie tyle wspólnotowe, ile dokonało się na oczach wspólnoty, pozostając jednak własne, osobne i osobowe.

Rzadko jednak wizerunek na olimpijskim podium pozostaje wolny od potrzeby autokomentarza, odsyłającego do katalogu konkretnych wartości. Deklarowanych ładnie i bez wątpienia uczciwie, ale zgodnych z oczekiwaniami na coś przekraczającego sens gry wyłącznie sportowej. Złote wioślarki z igrzysk w Rio, Magdalena Fularczyk-Kozłowska i Natalia Madaj wysłuchały Mazurka Dąbrowskiego wpatrzone w figurę górującego nad Rio Chrystusa Odkupiciela „,czuwał nad nami, na treningach nie było go widać, a na startach tak"18. Anita Włodarczyk, mistrzyni rzucania młotem, wyznała w Rio: ,kiedy wchodziłam na podium, pomyślałam o Kamili. Spojrzałam w niebo. Zreszta tak samo robię przed wejściem do koła, bo wiem, że Kamila gdzieś tam czuwa nade mna"19. Religia olimpijska jest w pewnym sensie uniwersalna, ale patronów sportowcy wybierają, jak Anita, Kamilę Skolimowską, na własny, intymny rachunek.

W rozpowszechnionym nawyku okrywania się przez sportsmenów flagą państwową po zwycięskim dotarciu do mety lub po ostatnim dającym pierwszą lokatę skoku czy rzucie, można dostrzec potrzebę schronienia się pod namiotem

${ }^{13}$ P. Wołosik, Do takich ludzi należy świat!, „Przegląd Sportowy” 14.02. 2014.

${ }^{14}$ E. Goffman, Rytuat interakcyjny, Warszawa: Wydawnictwo Naukowe PWN 2006, s. 7.

${ }^{15}$ K. Wolnicki, Wzruszona mistrzyni, „Przegląd Sportowy” 14.02. 2014.

${ }^{16} \mathrm{http} / / / \mathrm{www}$. fakt.pl/sport/inne-sporty/mazurek-dabrowskiego-zabrzmial-dwa-razy/xx0khdy

17 Tamże.

18 https://sportowefakty.wp.pl/rio-2016/621819/chrystus-odkupiciel-pomogl-polkom-zdobyczloto-czuwal-nad-nami

${ }^{19} \mathrm{http}$ ://www.przegladsportowy.pl/igrzyska-olimpijskie/rio-2016, anita-wlodarczyk-na-ceremoniwreczenia-medali,artykul,711129,1,13452.html 
lub nakrycia się płótnem, które na zawsze będzie niedostępne przegranym, a więc nagim w swej goryczy i bezsilności. Przed startem do biegu, przed pierwszą kolejką rzutów, wyobraźnia zawodnika wypatruje sztandaru z taką samą zapewne nadzieją i wiarą, jak czynili to piesi i konni wojownicy przed decydującą bitwą na ubitym (a niedługo później zazwyczaj upitym) polu. Niekiedy walczono na śmierć i życie u stóp gór czy na przełęczach, mając w zasięgu wzroku ośnieżone szczyty.

„Wznieśli się na Mount Everest swoich możliwości” ${ }^{20}$ - wygłosił lapidarną pochwałę siatkarzy, zwycięzców igrzysk w Montrealu, ich trener Hubert Wagner. „Moja mała biało-czerwona choragiewka z boiska musi wyrosnać w wielki sztandar i zawisnać na najwyższym maszcie"21 - opisywała swoje olimpijskie marzenie Halina Konopacka, pierwsza polska złota medalistka, mistrzyni dysku igrzysk w Amsterdamie. „Gdy stałam na podium znów byłam najszczęśliwszym człowiekiem na świecie” - zwierzyła się Irena Szewińska po olimpijskiej wygranej na 200 metrów w Meksyku. Po drugiej stronie najważniejszego, złotego medalu, chcemy dostrzec coś wzorcowego. Jak twierdzi Józef Lipiec „,...) każdy realny akt sportowy jest stanem wartościorodnym, a podmiotowość $w$ wyborze i kreacji aksjologicznej przystuguje $z$ istoty każdemu zawodnikowi" ${ }^{\prime 22}$. Tyle że ta kreacja aksjologiczna najprościej i najbardziej sugestywnie dotyka nie tylko sportowego czynu, lecz i również sztandaru, pod którym czyn się taki dokonał.

Wyłanianie najszybszego na mecie, najcelniej trafiającego do tarczy, najsilniej uderzającego rękawicą lub wykonującego najsprawniej piruety na lodzie, dokonuje się na igrzyskach olimpijskich naprawdę, ale chwałę z pierwszeństwa czerpie nie tylko nagradzana złotem medalem jednostka. Autor „Filozofii olimpizmu” podkreśla: „,sportowiec występuje jako uprzedmiotowiony element większej catości, jest bowiem przez dana społeczność wybierany, zgłaszany i firmowany"23.

To w imieniu tej społeczności sportowiec przekracza niekiedy konwencję. $\mathrm{Na}$ igrzyskach w Monachium Bernd Kannenberg, zwycięzca chodziarskiego maratonu na 50 kilometrów, reprezentant Niemiec jeszcze wówczas określanych jako Niemcy Zachodnie, zaprosił na pierwszy stopień podium rywali ze Związku Sowieckiego i Stanów Zjednoczonych. Według zapisków dziennikarzy, medaliści wysłuchali wspólnie hymnu triumfatora. Mimowolni olimpijscy alianci dowiedli tym samym, że wygrane ludzi z innymi ludźmi opowiadają inaczej (a może lepiej) o wynikach wojen z przeszłości i jak najlepiej wróżą o nie tylko olimpijskim pokoju. Aborygenka Catherine Astrid Salome Freeman wygrała dla Australii wyścig na 400 metrów podczas igrzysk w Sydney. Wygrała dla gospodarzy i gospodyń, ale również dla Aborygenów, których bezlitośnie z własnych gospodarstw wygnano. Jako pierwsza pokonała nie tylko jedno okrążenie stadionu, ale obręcz historii, w której finale

${ }^{20}$ G. Wagner, K. Mecner, Kat. Biografia Huberta Wagnera, Warszawa: Agora SA 2014, s.136.

${ }^{21}$ J. Lis, Legenda tamtych lat... [w:] Poczet polskich olimpijczyków 1924-1984. Paryż’ 24, Amsterdam' 28, Los Angeles' 32, Warszawa: Krajowa Agencja Wydawnicza 1984, s. 28.

22 J. Lipiec, Filozofia olimpizmu, Warszawa: Polskie Wydawnictwo Sportowe SPRINT 1999, s. 122.

${ }^{23}$ Tamże, s. 111. 
można było pieczętować tożsamość trzymanymi w zwycięskich dłoniach flagą australijską i tej samej, trudniejszej wielkości flagą aborygeńską. To podczas igrzysk olimpijskich w ceremonii otwarcia, wspólnie defilowały reprezentacje obydwu państw koreańskich, pod flagą z niebieską mapą całej Korei na białym tle. Niewinna biel była dla obydwu Korei jak dotąd ekspozycją jedynie letnich igrzysk w Sydney i w Atenach. Ale i tak lepiej wróży niż przechwałka strzelca o nazwisku Ho-Jun Li, mistrza olimpijskiego z Monachium, który na pytanie o źródła perfekcyjnego trafiania w centrum tarczy, wyjaśnił: „cały czas powtarzałem sobie, że strzelam do wroga"24. Prawdziwą wojnę i prawdziwe strzelanie poznał podczas II wojny światowej Alain Mimoun, mistrz igrzysk w Melbourne. Na mecie maratonu ,chciat, by mu dali spokój. Dopiero gdy zagrali Marsyliankę, (...) wzruszyt się ${ }^{\prime 25}$. Inny maratończyk, ale biegający na nartach - Norweg Bjoern Daehlie, na igrzyskach w Nagano, po minięciu mety przez dwie godziny poddawany był reanimacji. O jego zwycięstwie pisze Marek Jóźwik: „zdecydowały ułamki sekund $i$ cate sportowe życie, które postawit na jedna kartę. Tylko on wie, jaka zapłacit cenę za kolejna złota blaszkę. Ale na pewno by się nie targowat, gdyby przyszło mu to zrobić jeszcze raz"26.

Każdy sportowiec oczyma wyobraźni widzi podium, na którego stopień najwyższy ceremoniał nakazuje najlepszemu wejść u kresu dekoracji, w zgodzie z prawdą, że ostatni bywają pierwszymi przynajmniej pod mikroskopem świata, na stadionie wypełnionym mrówkami z chorągiewkami. Podium olimpijskie ma tylko trzy stopnie, ale aby wspiąć się najwyżej trzeba pokonać wszystkich, którzy pragną tego samego.

W „Czwartej odzie” (z cyklu „Ód olimpijskich”) Jarosław Iwaszkiewicz przestrzegat: „tylko braterstwo ludów może wnieść na maszt / olbrzymia jak świat flage olimpijska" ${ }^{27}$. Są flagi większe i mniejsze. Poezja także zdarza się albo monumentalna, albo zdecydowanie skromniejszych zamiarów. Jakoś mi bliżej do lirycznej autopromocji Cassiusa Claya, opublikowanej krótko po tym, jak w finale rzymskich igrzysk pozbawił nadziei Zbigniewa Pietrzykowskiego: ,Chwała Ameryki mi zawsze przyświeca, / Pokonałem Polaka i Sowieta, / Flagę Stanów blask złota znów opromienia" ${ }^{28}$. Igrzyska olimpijskie są na pewno zastępczą grą z losem, nie przestając być lustrem, w którym przegląda się życie - ani lepsze, ani gorsze od tego, które dzieje się na stadionie.

${ }^{24}$ T. Olszański, dz. cyt., s. 69.

25 B. Tomaszewski, Moich dziesięć olimpiad, Warszawa: Krajowa Agencja Wydawnicza 1980, s.73.

${ }^{26}$ M. Jóźwik, Cyrk blagiera, Warszawa: Twój Styl Wydawnictwo Książkowe 2004, s. 199.

27 J. Iwaszkiewicz, Oda czwarta [w:] M. Grześczak, Stadion ze słów, Warszawa: Krajowa Agencja Wydawnicza 1985, s. 165.

${ }^{28}$ T. Hausner, Muhammad Ali. Moje życie. Moja walka, Kraków: Wydawnictwo Veni Vidi Vici 2013, s. 28. 


\section{BIBLIOGRAFIA}

Goffman E., Człowiek w teatrze życia codziennego, Warszawa: Wydawnictwo KR 2000.

Goffman E., Rytuat interakcyjny, Warszawa: Wydawnictwo Naukowe PWN 2006.

Hausner T., Muhammad Ali. Moje życie. Moja walka, Kraków: Wydawnictwo Veni Vidi Vici 2013. Iwaszkiewicz J., Oda czwarta [w:] M. Grześczak, Stadion ze stów, Warszawa: Krajowa Agencja Wydawnicza 1985.

Jóźwik M., Cyrk blagiera, Warszawa: Twój Styl Wydawnictwo Książkowe 2004.

Kozakiewicz W., Pol M., Nie mówcie mi jak mam żyć, Warszawa: Agora SA 2013.

Lipiec J., Filozofia olimpizmu, Warszawa: Polskie Wydawnictwo Sportowe SPRINT 1999.

Lipiec J., Sympozjon olimpijski, Kraków: Wydawnictwo Fall 2014.

Lis J., Legenda tamtych lat... [w:] Poczet polskich olimpijczyków 1924-1984. Paryż’ 24, Amsterdam'

28, Los Angeles' 32, Warszawa: Krajowa Agencja Wydawnicza 1984.

Olszański T., Osobista historia olimpiad, Warszawa: Wydawnictwo Studio EMKA 2004.

Passent D., Biada, wołajcie, lecz niech zwycięża radość [w:] Sport niejedno ma imię, Warszawa:

Wydawnictwo „Sport i Turystyka” 1976.

Sportowcy trzydziestolecia, Warszawa: Wydawnictwo „Sport i Turystyka” 1974.

Staszewski W., Śpiewać hymn nie każdy może, „Gazeta Wyborcza” („Duży Format”) 14.11. 2010.

Strzyżewski W., Złota szabla [w:] Opowiadania sportowe, Warszawa: Wydawnictwo „Sport i Turystyka" 1971.

Tomaszewski B., Listy oldboya czyli olimpijskie Samosierry, Warszawa: Wydawnictwo „Sport i Turystyka" 1974.

Tomaszewski B., Moich dziesięć olimpiad, Warszawa: Krajowa Agencja Wydawnicza 1980.

Wagner G., Mecner K., Kat. Biografia Huberta Wagnera, Warszawa: Agora SA 2014.

Wolnicki K., Wzruszona mistrzyni, „Przegląd Sportowy” 14.02. 2014.

Wołosik P., Do takich ludzi należy świat!, „Przegląd Sportowy” 14.02. 2014.

\section{Internet}

http://eurosport.onet.pl

http://www.fakt.pl

http://www.przegladsportowy.pl

https://sportowefakty.wp.pl

\section{Streszczenie}

Barwy narodowe i hymn są elementem zarówno tożsamości, jak i autokreacji aktora sceny sportowej. Zachowania mistrzów olimpijskich recenzowano w języku teatru i niekiedy w języku polityki. Współcześnie zwycięzca igrzysk olimpijskich, pierwszoplanowy aktor widowiska, jest świadomym reżyserem epilogu prowadzonej przez siebie gry i scenariuszowi honorowania najlepszych nadaje własny rys. Jednocześnie od zdobywcy najwyższego lauru nadal oczekuje się solidarności z wartościami identyfikującymi rywalizację jednostek jako konfrontację państw i narodów. Ogrywanie ceremoniału gry sportowej przez jego uczestnika ma - mimo ewolucji samego kształtu widowiska - naturę konserwatywną, odpowiadając wyobrażeniom odbiorców.

Dokonane rozpoznania wykorzystały relacje i opisy dostępne w prasie i na portalach internetowych, a także świadectwa obecne w literaturze sportowej, w reportażu i publicystyce.

Słowa kluczowe: hymn, propaganda, rywalizacja, igrzyska olimpijskie, sport 


\title{
VARIOUSLY CREATED MELODY
}

\begin{abstract}
Sum mary
National colours and anthem are the elements of both identity and autocreation of the sport stage's actor. The behaviour of Olympic champions has been a subject to reviews made in the language of theatre and, sometimes, the language of politics. Nowadays, an Olympic champion, the leading actor of the spectacle, is a self-aware director of the epilogue to their own play, and adds a personal touch to the award ceremony's scenario. Simultaneously, solidarity with the values that perceive the individual rivalry as a confrontation between countries and nations is expected from an Olympic champion. The acting out of the sports game's ceremony by its players maintains (despite the evolution of the spectacle itself) a conservative nature that corresponds with the spectators' ideas.

Reports and descriptions available in press and Internet sources were used during the reconnaissance, as well as the relations available in sport's literature, reportage and journalism.
\end{abstract}

Keywords: anthem, propaganda, rivalry, Olympic Games , sport 